\title{
Women Employment in terms of Gender Inequality across the Provinces of Turkey
}

\author{
Fatih CELEBIOGLU *
}

\begin{abstract}
Inequalities are very important and multi-dimensional problem for all countries in the world. Particularly, the problem is challenging for developing countries due to the presence of not equal opportunities in economic life. This study aims to examine relations between women employment and socio-economic inequalities by using spatial data and techniques across the regions of Turkey. We use women employment's share in total employment of provinces in 2014 as an indicator of women employment as long as the following variables used as independent are Gender Equality Index, Socio-Economic Development Index, gender based wage gap and household size.

To test spatial dimensions of the variables, firstly we perform an Exploratory Spatial Data Analysis on all variables for provinces of Turkey. Secondly, we explain spatial econometrics dimensions of women employment in Turkey. The results indicate that spatial regression is statistically significant and have high level of coefficient of determination in terms of spatial lag and error models. The study results indicate the significant relations among independent variables and women employment. Overall, our results show new dimensions of spatial distribution of women employment in Turkey.
\end{abstract}

Keywords: Women Employment, Gender Inequality, Gender Wage Gap, Spatial Analysis, Turkey

JEL Code Classification: J21, R12, C21

UDC : 331.5.024.5-005.2(560)

DOI: https://doi.org/10.17015/ejbe.2017.019.04

\footnotetext{
* Associate Professor, Dumlupınar University, Department. of Economics, Kütahya, TURKEY

E-mail: fatih.celebioglu@dpu.edu.tr

Copyright (C, 2017 International Ataturk Alatoo University.
} 


\section{Introduction}

There are many kinds of inequality in the world and each one of them is undesirable for societies. An important one of these is gender inequality. As indicated in the Equity and Development Report (2006), it occurs as a result of different set of economic, social, cultural, and political inequalities that reinforce each other. These inequalities cause women to have less access to property rights, wealth, and education - and limit their access to labor markets and to spheres of activity outside the home. This, in turn, constrains their ability to influence household decisions (World Bank, 2006:54).

In World Bank Report 2012, it is briefly explained how gender equality can enhance economic efficiency and make contribution on achievement of key development outcomes in three ways. First of all, overcoming obstacles that prevent women's equal accessibility as men to education, economic opportunities, and productive inputs. Second, improving women's absolute and relative status feeds many other development outcomes, including those for their children. Third, enhancing the playing field of women in social and political life to lead over time to more representative, and more inclusive, institutions and policy choices and thus to a better development path (World Bank, 2012:3).

Although all countries suffer from gender inequalities, it is mostly observed in developing ones. In Turkey, as an upper middle-income country, gender inequality is still a problem concerning social and economic aspects. In this paper we mainly focus on socio-economic inequalities that effect women employment level across the provinces of Turkey.

In recent years, important EU reforms, implementations of positive discrimination and legislations have positively affected the status of women in economic life. Although all important alterations, women employment level in Turkey is lower than EU countries. Beside there is no unique structure for women employment across the regions of country.

The main contribution of this paper is to examine women employment in terms of inequalities by using spatial data and techniques across the regions of Turkey. We use women employment's share in total employment of provinces in 2014 as an indicator of women employment. Gender Equality Index, Socio-Economic Development Index (SEDI), gender based wage gap and household size are used as independent variables. According to our findings, there are significant spatial relations among independent variables and women employment.

The rest of the paper is organized as follows: the second section provides literature review regarding the subject of the study; the third section explains data and methodology of the paper; the fourth one interprets findings of empirical analysis and the last section is conclusion. 


\section{Literature Review}

Gender inequality is examined in a variety of aspects in the literature. In terms of economics, it is generally expressed as inequalities in education, employment and wage. All these dimensions of inequalities are connected to each other and they effects economies in a significant way. A large body of studies shows that rising gender inequality has negative effects on economic development and growth especially in developing countries (Dollar \& Gatti, 1999; Klasen, 1999; Blackden \& Bhanu, 1999; Abu-Ghaida \& Klasen, 2002; Klasen \& Lamanna, 2009; Ward et al., 2010; Kabeer \& Natali, 2013).

As a developing country, Turkey has been working to reduce gender inequality and to increase women employment level in the last decade. Despite the significant growth experiences in this period women employment level is still low in comparison to developed countries.

Although there has been an extensive literature on the factors affecting the women's participation in the labor force in Turkey, studies that are focused on gender inequality are relatively less. In addition, studies which examine genderbased socio-economic inequalities by taking into account spatial effects at provincial base are very limited. Here, we present key factors demonstrated in many studies which led to inequalities in terms of women employment.

Education has come to the fore as a fundamental factor that determines female labor force participation in the literature related to women employment in Turkey (Dayıoğlu \& Kırdar, 2010; Kızılgöz, 2012; Önder, 2013; Göksel, 2013; Kılıç \& Öztürk, 2014; Inan \& Aşık, 2015). Therefore understanding gender inequality in education is crucially important to analyze women employment.

Tansel (2001) analyzed female labor force participation rates in Turkey by considering its cross-provincial determinants with time series evidence. Female education was found to have a strong positive effect on female labor force participation. In addition, significant regional disparities in female labor force participation were found in the study. According to the results, Mediterranean, Central Anatolia, Southeast Anatolia and East Anatolia had significantly lower female labor force participation rates than Marmara while Black Sea had higher female participation rates and Aegean was not significantly different from Marmara. According to Rankin and Aytaç (2006), at the macro structural level, gender differences in schooling stems from urbanization level of provinces. On the other hand, patriarchal family beliefs are also strong determinants of gender inequality in Turkish education.

Caner et al. (2015) used data on views about gender roles from the Turkish Demographic and Health Surveys. They took 1998 and 2003 rounds of the TDHS to see the effects of 1997 education reform. Results showed that the reform helped reduce school dropout rates across the country. However they claimed that reform 
failed to eliminate the gender gap against girls because, regardless of the mother's view on gender roles, the reductions in school dropout rates were similar for boys and girls.

To the best of our knowledge, there has been found one study that considers spatial dimensions of gender inequality in education in Turkey. Filiztekin and Karahasan (2015) demonstrate the spatial distribution of educational attainment in Turkey based on district level data for 1990 and 2010. Findings indicate that different segments of the society realize different levels of improvement in education attainment. Female population and rural population are observed to be the most disadvantageous individuals. Besides, analysis for the spatial dependence of educational attainment highlights that the highest spatial spillovers are observed among the most unequal groups of the society.

Another important inequality type effecting women employment is gender-based wage gap. Önder (2013) emphasizes that low wages took first place among leave of employment reasons in his study. There are many cultural and economic reasons lies under this situation. In a variety of studies (Kasnakoğlu \& Dayıoğlu 1996; Ercan \& Tunalı, 1998; Tansel, 1994, 1999; Dayığlu \& Tunalı, 2003) it is found significant differences in the hourly earnings of men and women by using Oaxaca-Blinder type decomposition methods. Studies indicated that it is not the endowment differences that lead to the wage gap but rather the higher market valuation of male traits (Dayıoğlu \& Kırdar, 2010:8). Ilkkaracan and Selim (2007) also examined the sources of wage inequality between female and male labor force at sectorial base in Turkey by using matched employer-employee data and found that a large portion of the gender wage gap is attributable to women's considerably lower levels of work experience and job tenure.

Dinc and Budic (2016) examined the relationship between demographic variables, personal attitude, subjective norm, perceived behavioural control, and entrepreneurial intentions of women in Federation of Bosnia and Herzegovina. Relationships between the variables were evaluated using factor analysis, reliability, correlations, descriptive statistics, and regression. The findings show a positive and significant influence of personal attitude and perceived behavioural control on entrepreneurial intention.

According to Inan and Aşık (2015:20) in report of OXFAM and TEPAV, gender pay gap persists even taking education into account. In 2010, the gender wage gap was in favor of women as a whole $(-1.1 \%)$ but in favor of males on all education levels. Wages increase with the level of education for both men and women but the return to education is higher for men than women. 


\section{Data and Methodology}

Women employment data comes from Social Security Institution ${ }^{1}$ of Turkey. Household size and divorce rate data sets are taken from Turkish Statistical Institute (TurkStat) ${ }^{2}$. Gender Equality Index is calculated by The Economic Policy Research Foundation of Turkey (TEPAV) ${ }^{3}$. Gender Equality Index, women's share in employment, gender based wage gap and household size are in 2014. SEDI data comes from the Ministry of Development ${ }^{4}$, which were designed in 2003 and 2011. We use SEDI data for 2011 in the paper.

We have some limitations about the dataset. For instance, Gender Equity Index data calculated for only 2014. Also we don't have new version of SEDI data after 2011. For this reason, we cannot get a comparison between two different periods.

\subsection{Spatial Statistic Analysis with Exploratory Spatial Data Analysis (ESDA)}

To test spatial dimensions of the variables, we perform an Exploratory Spatial Data Analysis (ESDA) on all variables for provinces of Turkey. While our choropleth maps indicate that the some part of the country is significantly more developed than the others, the tools of spatial statistics reveal the presence of spatial dependence across provinces. Moran's I values and Moran's scatterplots show effectively global autocorrelations. The presence of heterogeneity is reflected in the distribution of Local Indicators of Spatial Association statistics (LISA).

Spatial autocorrelation means that correlation of a variable in space. If this correlation value is positive, high values associate with high proximity values, or vice versa. If this correlation value is negative, high values correlate with low neighbors values (outliers for high-low), or vice versa. Spatial autocorrelation test is done for both global (test for clustering) and local (test for clusters) Moran's I Statistics. Global spatial autocorrelation is a size of whole clustering, and it is measured by Moran's I. It is evaluated by virtue of randomly located test of a null hypothesis. If this null hypothesis is rejected, it increases our comprehension about our data set and its spatial structure. It measures the location of a spatially mean value and spatially weighted neighboring value of a variable (see Anselin, 1995; Anselin, Syabri \& Kho,2006; Anselin, Sridharan \& Gholston, 2007).

$I_{t}=\frac{\sum_{i=1}^{n} \sum_{j=1}^{n} w_{l l}(k) x_{l t} x_{j t}}{\sum_{i=1}^{n} \sum_{j=1}^{n} x_{i t} x_{j t}}$

Where $\dot{W}_{l l}$ is the degree of relation between spatial unit $\mathrm{i}$ and $\mathrm{j}, x_{i t}$ is the deviation of $i$ variable from average for the year $t$. If the value of $I$ is larger than expected

\footnotetext{
${ }^{1}$ www.sgk.gov.tr

${ }^{2}$ www.tuik.gov.tr

${ }^{3}$ www.tepav.org.tr

${ }^{4}$ www.kalkinma.gov.tr
} 
value, spatial autocorrelation displays positive value, vice versa. At this study, we used 999 permutations for dataset at the calculation of I statistic.

The results of Moran's I are given (see Table C1). All the results indicate a positive spatial autocorrelation, i.e. the value of a variable in one location depends positively on the value of the same variable in neighboring locations. For instance, when the women employment rate in one province increases by $1 \%$, the one of its neighbors increases by slightly more than approximately by $0.66 \%$ (for rook matrix). All variables are significant (at $1 \%$ ) with the K-nearest 7, K-nearest $8, \mathrm{~K}$ nearest 9, queen, and rook matrixes. Because of Moran's I value of variables is mostly the highest value for rook matrix, we decided to use rook.

LISA measures, by definition, the presence of spatial autocorrelation for each of the location of our sample. It captures the presence or absence of significant spatial clusters or outliers for each location. Combined with the classification into four types defined in the Moran scatter plot above, LISA indicates significant local clusters (high-high or low-low) or local spatial outliers (high-low or low-high). The average of the Local Moran statistics is proportional to the Global Moran's I value (see Anselin, 1995; Anselin et al.2007).

Formulation of the local Moran's statistics for each region $i$ and year $t$ as the follows (Anselin, 1995):

$I_{i}=\left(\frac{x_{i}}{m_{o}}\right) \sum_{j} w_{i j} x_{j}$ with $m_{o}=\sum_{i} x_{i}^{2} / n$

where $w_{i j}$ is the elements of the row-standardized weights matrix $\mathrm{W}$ and $x_{i}\left(x_{j}\right)$ is the observation in region $i(j)$. The LISA statistics is significant at $5 \%$. Their significance level is based on a randomization approach with 999 permutations of the neighboring provinces for each observation.

\subsection{Spatial Econometric Analysis}

We also explain spatial econometrics dimensions of women employment in Turkey. For this reason, spatial lag and spatial error models are tested for all variables.

Incorporates spatial effects by including a spatially lagged dependent variable as an additional predictor:

$$
y=\rho W y+x \beta+\varepsilon
$$

where $w_{y}$ is spatially lagged dependent variable for weights matrix $W, x$ is a matrix of observations on explanatory variables, $\varepsilon$ is a vector of error terms, $\rho$ is the spatial coefficient. If there is no spatial dependence, and y does not depend on neighboring y values, $\rho=0$.

Incorporates spatial effects through error term;

$$
y=x \beta+\varepsilon
$$


$\varepsilon=\lambda W \varepsilon+\zeta$

Where $\varepsilon$ is the vector of error terms, spatially weighted using the weight matrix ( $W), \lambda$ is the spatial error coefficient and $\zeta$ is a vector of uncorrelated error terms. If there is no spatial correlation between the errors, then $\lambda=0$.

\section{Findings}

The choropleth maps (see Figure A1 to A5 in Appendix A) reflect generally EastWest inequalities in Turkey. These inequalities dominate social-economic life in the country. Darker areas in the choropleth maps show higher values of variables. Lighter areas in the maps show lower values of variables.

Firstly, when we investigate the share of women employment in total employment for all provinces in Turkey, share of women employment is higher in West parts of Turkey. Especially more women can be employed in the coastal parts and industrialized cities of the country due to developed tourism sector and industrial investments. But other remarkable point for distribution of the variable is about socio-cultural structure of some provinces. Some families don't culturally allow to working of women in more conservative cities and regions of the country.

The second Choropleth Map A2 is about wages difference in Turkey. Although wage difference data don't reflect very clear province level inequality, especially some provinces (such as Kocaeli, Sakarya, and Eskişehir) which have higher labor income are attract attention.

The other choropleth map explains household size of the provinces in Turkey (Choropleth Map A3). Traditional family structure, mostly agriculture based economy, less educated society in the Southeastern Anatolia cause bigger size families. Internal migration and negative effects of urbanization on disposable income has been decreasing number of children in Western part of Turkey.

The Choropleth Map A4 shows Socio-Economic Development Index values of provinces in Turkey. Levels of socio-economic development are higher in East part of the country than West part of the country. East-West duality is very clear. Especially Southeastern Anatolia region is very poor, because of many reasons that as ethnic terror, lower demand structure, non-coastal area.

Other important variable that has been used in this paper is Gender Equality Index. Spatial distributions of the index values are showed in Choropleth Map A5. As seen in the map, gender equality is better in the West part of the country. Some Middle Anatolian and most of Eastern and Southeastern Anatolian provinces have lower values of Gender Equality.

Almost all choropleth maps indicate remarkable regional disparity. For this reason, we can use Exploratory Spatial Data Analysis (ESDA) method to show more detail about disparity. After this point, we shall explain our findings about Moran's Scatterplots. 
All scatterplots show an important evidence of province level inequality. Provinces are mostly in High-High and Low-Low areas. As a consequence, Moran's I values of variables are quite high and P-values are significant. Moran's I values of household size, SEDI, gender equity and wage difference are respectively $0.86,0.57,0.43$ and 0.20 while share of women employment as a dependent variable of the paper has 0.66 (see all Moran's Scatterplots in Figure B1 to B5 in Appendix B).

To show the presence of spatial autocorrelation for each of the location of our sample, we bring out LISA cluster maps (see Figure D1 to D5 in Appendix D). Our first LISA Cluster Map D1 is about Women Employment's Share in total employment for all provinces in Turkey. When we look at the map, provinces that have been in High-High area (red colors, 13 provinces) are completely in West part of Turkey. East and Southeast Anatolian provinces are in Low-Low area (blue colors, 15 provinces). As seen, the West is a center for positive spatial autocorrelation about women employment.

The second LISA Cluster Map D2 is for wages difference in Turkey. As we mentioned above, wage difference variable has lower Moran's I value, beside LISA distribution of the variable is also not very clear as much as the others. Mostly provinces which are the west part of Black Sea Region and the south part of Marmara Region are in High-High area (10 provinces).

LISA Cluster Map D3 which is about household size show very high disparity. In the West part of Turkey, many provinces are in blue areas. It means that in this area is a cluster of lower household size (20 provinces). Beside East part of Turkey (especially Southeastern Anatolia region) is a cluster of higher household size (13 provinces).

Distribution of SEDI values are shown on LISA Cluster Map D4. While Western provinces (10 provinces) are in up levels of index, Eastern provinces (15 provinces) have lower index values. Provinces (such as İstanbul, Kocaeli, Balıkesir, Manisa, Aydın and Konya) compose a positive spatial autocorrelation center about socioeconomic development (Location and Names of Provinces in Turkey are given in Figure F1).

LISA Cluster Map D5 shows Gender Equality Index values of provinces. In the map, we can see positive and negative spatial autocorrelations (respectively blue and red areas in the map). Some Marmara and Aegean region provinces compose positive spatial autocorrelation (12 provinces). Again the West part of Turkey has better values of gender equality than East part of the country.

After LISA cluster analysis, we focus on spatial econometric dimensions of the dataset. Dependent variable is share of women employment. Independent variables are SEDI, wage difference, household size, and gender equality. First of all, we perform classic OLS regression (see Table E1 to E4 in Appendix E). According to classic OLS regression (see Table E1), SEDI, household size and gender equality 
are significant at $1 \%$. Beside wage difference is significant at $\% 10 . \mathrm{R}^{2}$ value of regression is 0.74 .

Secondly, we test OLS regression with rook weight matrix to see spatial dependence. OLS regression results with rook weight matrix (Table E2) show that both Lagrange Multiplier (lag) and Lagrange Multiplier (error) are significant at $1 \%$. In this case, we perform separately both of them.

Third one, we test spatial lag model with rook weight matrix (see Tale E3). $R^{2}$ value of regression is 0.79 . Spatial lag model results indicate that significant level of likelihood ratio test (diagnostics for spatial dependence) is $1 \%$. Also weighted share of women employment is significant at \%1. SEDI is significant at $10 \%$. But other variables (wage difference, gender equity and household size are significant at $1 \%$. According to regression results, if SEDI increase 1\%, this situation support women employment at rate of 0.009 . This rate for gender equality is -0.31 , for household size is -0.015 , and for wage difference is -0.0015 .

The last analysis is to test spatial error model with rook weight matrix (see Table E4). R-squared value of the regression reach the biggest (0.81) number. Results show that likelihood ratio test (diagnostics for spatial dependence) is significant at $1 \%$. Lambda is also significant at $1 \%$. The effects of independent variables on women employment's share as following: Gender equity $(-0.363)$, household size (0.022), wage difference (-0.001), and SEDI (0.012).

Overall results indicate that spatial regression is statistically significant and have high level of coefficient of determination in terms of spatial lag and error models.

\section{Conclusions}

Inequalities are very important and multi-dimensional problem for all countries in the world. Most of developed suggestions towards inequalities take a long time in every society. Particularly, the problem is challenging developing country, because of the countries focus on mostly fast growing, not equal opportunities in economic life. As a developing country, Turkey has also some problems about inequalities. The problem has social, cultural and economic dimensions as well. Gender inequality problem of Turkey dominate its labor markets. We focus on

In this paper, we investigate relations among women employment, gender inequality, wage gap, SEDI and household size across the provinces of Turkey. Firstly, we determine the regional disparities in Turkey in terms of our variables by using choropleth maps and Moran's I statistics. Secondly, we perform LISA cluster maps to show positive or negative spatial autocorrelations, in the other words positive or negative centers of attraction. After spatial statistics (ESDA analysis), we can say that the West part of Turkey more developed than the East part Turkey.

We test spatial lag and spatial error models. The models are significant and work effectively. Our spatial econometric analyses indicate some important results: To 
increase of socio-economic development level and to ensure gender equities in the provinces of Turkey enhance share of women employment. Identically, to decrease of household size and wage gap should be positively supported women employment in the labor market.

To realize this results, Turkey need more 'positive discrimination' for women in labor market in terms of wage, flexible employment period etc. Beside educational curriculum should be re-designed with equity based paradigm and universal standards. Women in economic life should be more effectively protected from mobbing, gender-based violence, and sexual harassment. In other words, security and protection have very pivotal role to increase of women employment in Turkey as a developing country.

\section{References}

Abu-Ghaida, D. \& Klasen, S. (2004). The costs of missing the Millennium Development Goal on gender equity. World Development, 32(7), 1075-1107. https://doi.org/10.1016/j.worlddev.2004.02.003

Anselin L. (1995), Local Indicator of Spatial Association - LISA. Geographical Analysis 27, 93115. http://dx.doi.org/10.1111/j.1538-4632.1995.tb00338.x

Anselin L., Syabri I. and Kho Y. (2006), GeoDa: an Introduction to Spatial Data Analysis. Geographical Analysis, 38, 5-22. http://dx.doi.org/10.1111/j.0016-7363.2005.00671.x

Anselin L., Sridharan S. and Gholston S. (2007), Using Exploratory Spatial Data Analysis to Leverage Social Indicator Databases: The Discovery of Interesting Patterns. Social Indicators Research 82, 287-309. http://dx.doi.org/10.1007/s11205-006-9034-x

Blackden, C. M. \& Bhanu, C. (1999). Gender, growth, and poverty reduction: Special program of assistance for Africa, 1998 status report on poverty in Sub-Saharan Africa (No. 428). https://doi.org/10.1596/0-8213-4468-4

Caner, A., Guven, C., Okten, C., \& Sakalli, S. O. (2016). Gender roles and the education gender gap in Turkey. Social Indicators Research, 129(3), 1231-1254.

Dayıoğlu, M. \& Kırdar, M. G. (2009). Determinants of and Trends in Labor Force Participation of Women in Turkey. Türkiye'de Kadınların İşgücüne Katılımında Belirleyici Faktörler ve Eğilimler".

Dayıoğlu, M. \& Tunalı, ì. (2003). Falling behind while catching up: Changes in the femalemale wage differential in urban Turkey, 1988 to 1994. In Annual Meeting of the Population Association of America.

Dinc, M., Budic, S. (2016). The Impact of Personal Attitude, Subjective Norm, and Perceived Behavioural Control on Entrepreneurial Intentions of Women, Eurasian Journal of Business and Economics, 9, (17), 23-35. https://doi.org/10.17015/ejbe.2016.017.02

Dollar, D. \& Roberta Gatti.( 1999). Gender inequality, income, and growth: are good times good for women?, 1. Washington, DC: Development Research Group, The World Bank.

Filiztekin, A. \& Karahasan, B. (2015). Mapping the Educational Attainment in Turkey. In EY International Congress on Economics II (EYC2015), November 5-6, 2015, Ankara, Turkey (No. 285). Ekonomik Yaklasim Association. 
Göksel, i. (2013). Female labor force participation in Turkey: The role of conservatism. In Women's Studies International Forum (Vol. 41, pp. 45-54). Pergamon. https://doi.org/10.1016/j.wsif.2013.04.006

Ilkkaracan, I. \& Selim, R. (2007). The gender wage gap in the Turkish labor market. Labour, 21(3), 563-593.https://doi.org/10.1111/j.1467-9914.2007.00378.x

Inan, F. \& Aşık Güneş (2015) Making Economies Work for Women: Female Labour Force Participation in Turkey, OXFAM \& TEPAV Report.

Kabeer, N. \& Natali, L. (2013). Gender Equality and Economic Growth: Is there a Win-Win?. IDS Working Papers, 2013(417), 1-58.https://doi.org/10.1111/j.2040-0209.2013.00417.x

Kasnakoglu, Z. \& Dayioglu, M. (1997). Female labor force participation and earnings differentials between genders in Turkey. Economic dimensions of gender inequality: A global perspective, 95-117.

Kılıç, D. \& Öztürk, S. (2014). Türkiye'de Kadınların İşgücüne Katılımı Önündeki Engeller ve Çözüm Yolları: Bir Ampirik Uygulama. Amme Idaresi Dergisi, 47(1), 107-130.

Kızılgöl, Ö. A. (2012). Kadınların işgücüne katılımının belirleyicileri: Ekonometrik bir analiz. Doğuş Üniversitesi Dergisi, 13 (1), 88-101.

Klasen, S. (1999). Does gender inequality reduce growth and development: Evidence from cross-country regressions (pp. 1-12). World Bank, Development Research Group, Poverty Reduction and Economic Management Network.

Klasen, S. \& Lamanna, F. (2009). The impact of gender inequality in education and employment on economic growth: new evidence for a panel of countries. Feminist economics, 15(3), 91-132.https://doi.org/10.1080/13545700902893106

Önder, N. (2013). Türkiye'de Kadın İşgücünün Görünümü. Çalışma Dünyası Dergisi, 1(1).

Rankin, B. H. \& Aytaç, I. A. (2006). Gender inequality in schooling: The case of Turkey. Sociology of Education, 79(1), 25-43.htps://doi.org/10.1177/003804070607900102

Tansel, A. (1994). Wage employment, earnings and returns to schooling for men and women in Turkey. Economics of Education Review, 13(4), 305-320. https://doi.org/10.1016/S02727757(05)80054-8

Tansel, A. (2001). Economic development and female labor force participation in Turkey: time-series evidence and cross-province estimates. Economic Research Forum for the Arab Countries, Iran \& Turkey.

Tansel, A. (2004). Public-private employment choice, wage differentials and gender in Turkey. IZA Discussion Paper No. 1262; Economic Research Forum Working Paper No. 9913

Tunall, I. \& Ercan, H. (1998). Labor market segmentation in Turkey. Main Characteristics and Trends of the Turkish Labor Market.

Ward, J., Lee, B., Baptist, S. \& Jackson, H. (2010). Evidence for Action: Gender Equality and Economic Growth. Chatham House and Vivideconomics.

World Bank. (2005). World Development Report 2006: Equity and Development. Washington, DC. https://openknowledge.worldbank.org/handle/10986/5988

World Bank. (2012). World Development Report 2012: Gender Equality and Development. Retrieved from https://openknowledge.worldbank.org/handle/10986/4391 
Fatih CELEBIOGLU

\section{Appendix A}

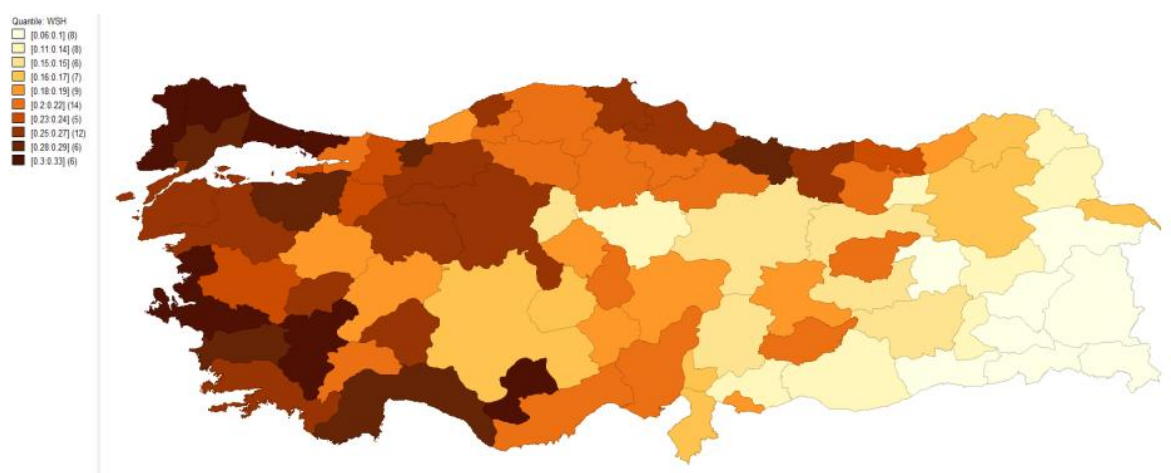

Figure A1. Choropleth Map: Women employment's share in total employment for all provinces in Turkey

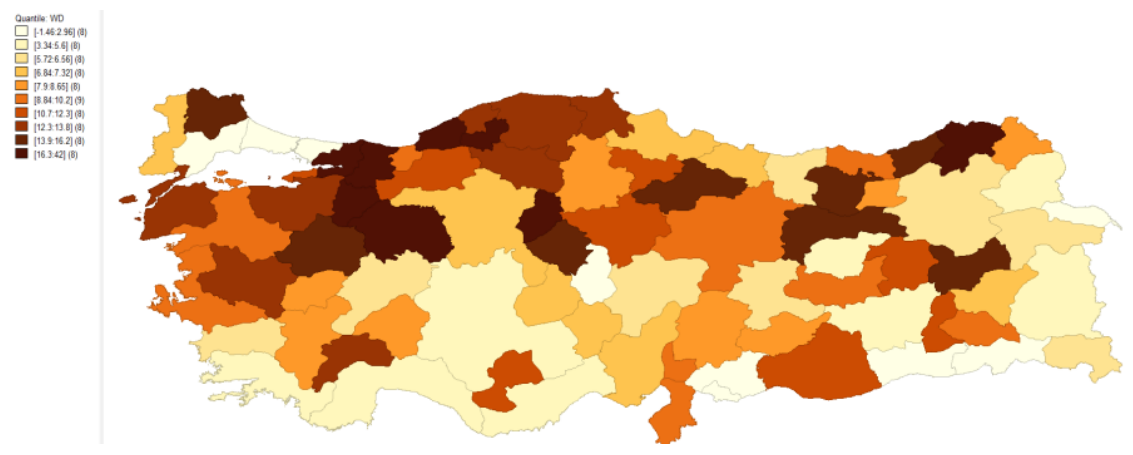

Figure A2. Choropleth Map: Wages difference for all provinces in Turkey
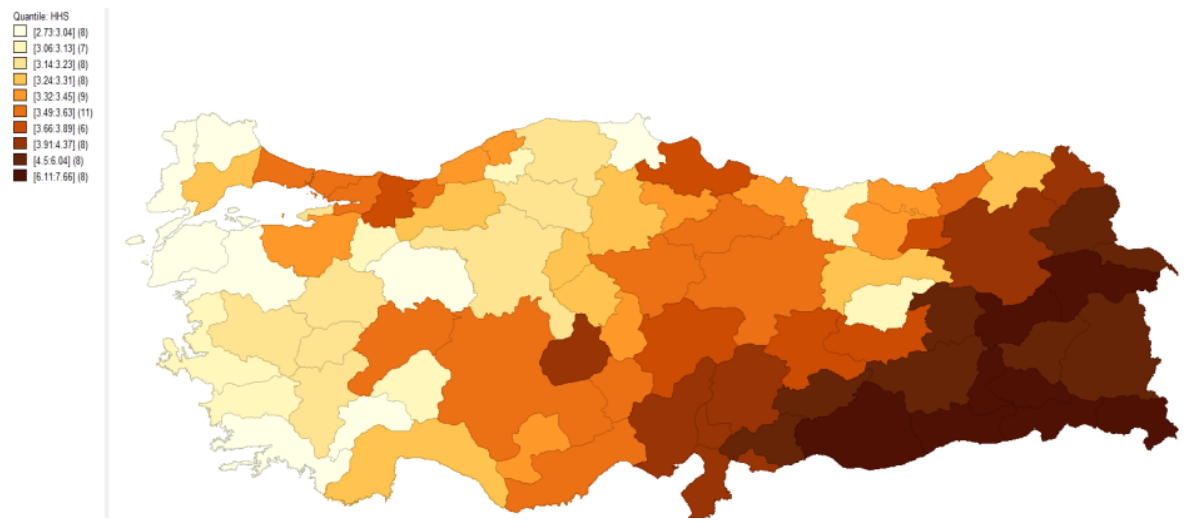

Figure A3. Choropleth Map: Household size for all provinces in Turkey 
Women Employment in terms of Gender Inequality across the Provinces of Turkey

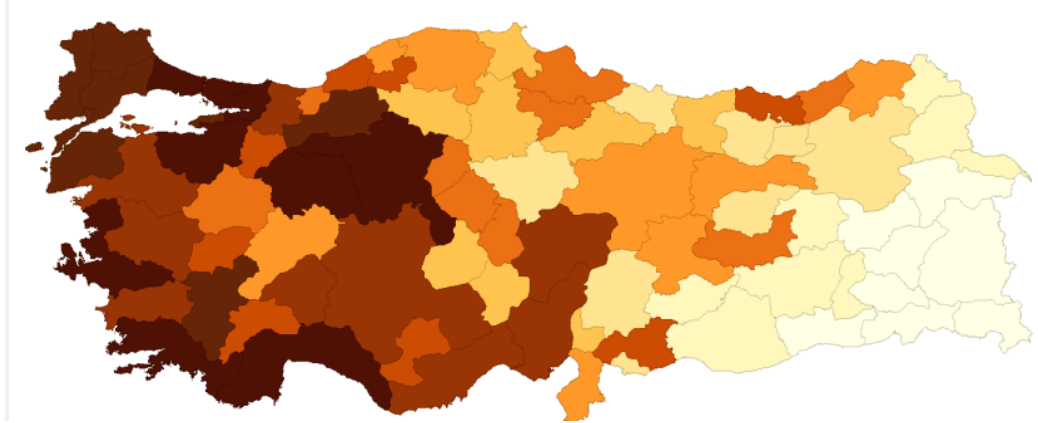

Figure A4. Choropleth Map: SEDI values for all provinces of Turkey in 2011

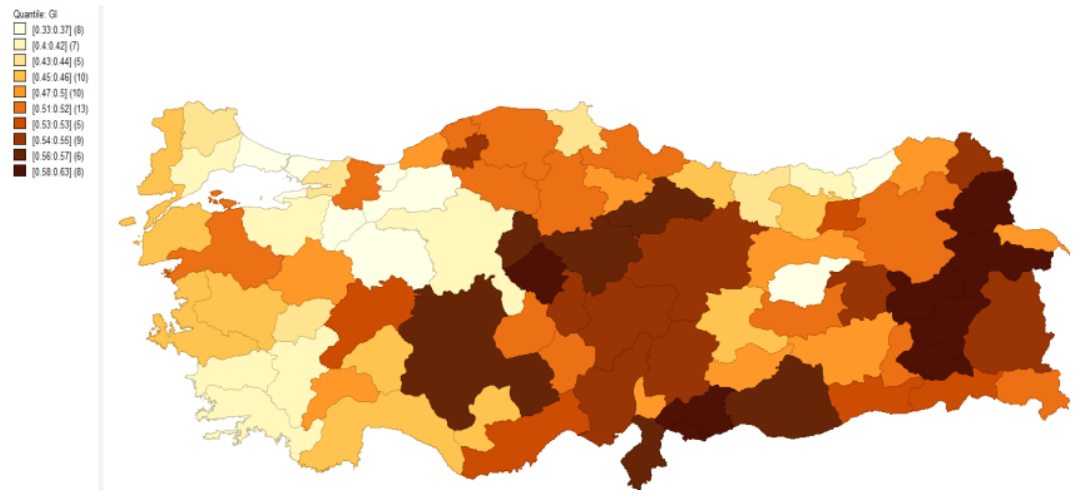

Figure A5. Choropleth Map: Gender Equality Index for all provinces in Turkey Appendix B

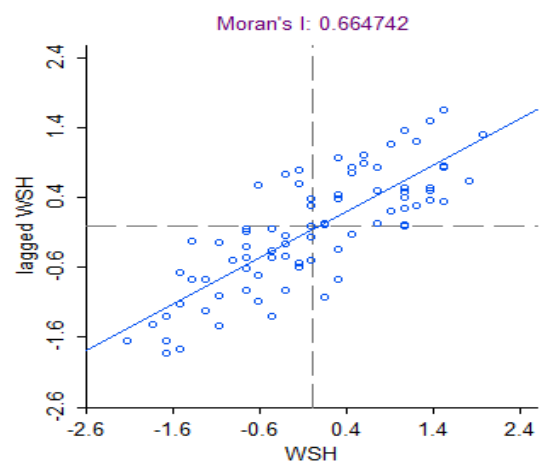

Figure B1. Moran's Scatterplot: Share of Women Employment

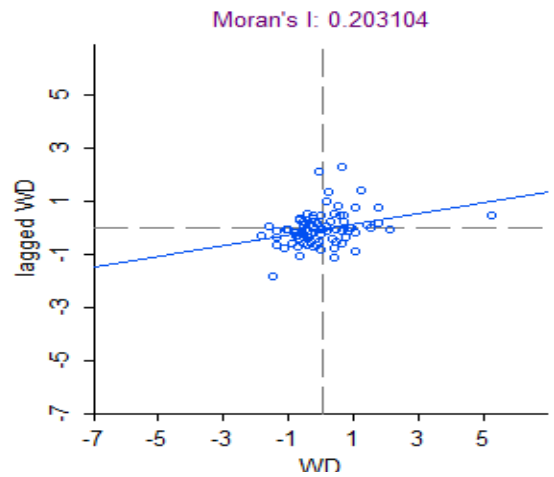

Figure B2. Moran's Scatterplot: Wages Difference 


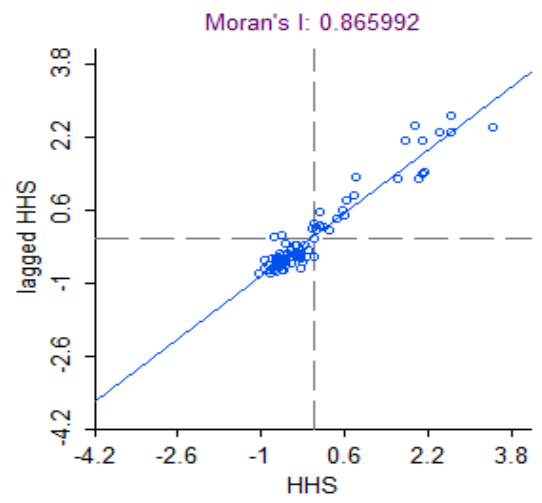

Figure B3. Moran's Scatterplot: Household Size

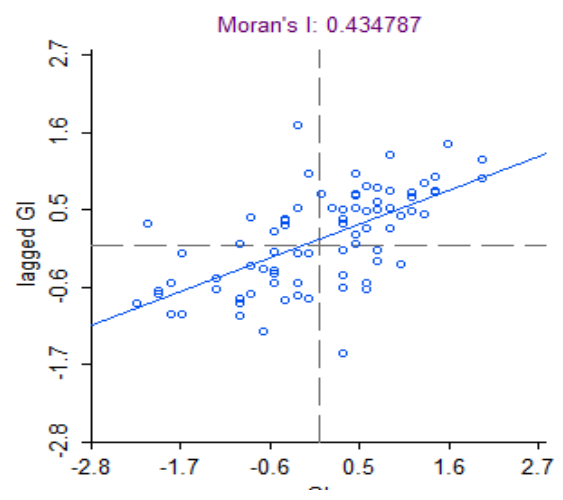

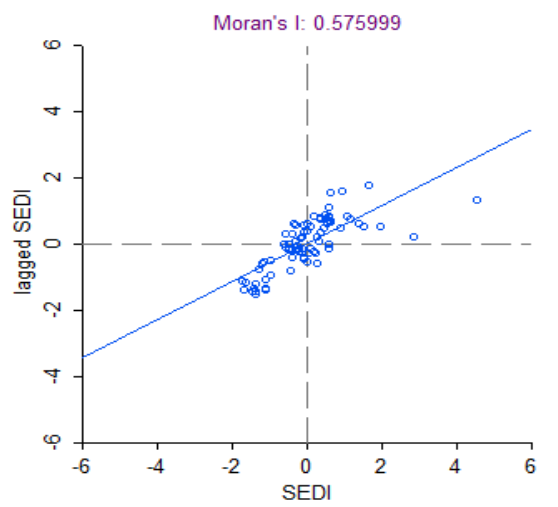

Figure B4. Moran's Scatterplot: SEDI

Figure B5. Moran's Scatterplot: Gender Equality Index

\section{Appendix C}

Table C1. Moran's I and P values of All Variables for Different Kinds of Weight Matrix

\begin{tabular}{llllll}
\hline & Queen & Rook & K_7 & K_8 & K_9 \\
\hline Women employment & 0.66502 & 0.664742 & 0.634439 & 0.62393 & 0.621122 \\
rate & $(0.001)$ & $(0.001)$ & $(0.001)$ & $(0.001)$ & $(0.001)$ \\
Wages difference & 0.198635 & 0.203104 & 0.1099 & 0.133646 & 0.131313 \\
& $(0.003)$ & $(0.004)$ & $(0.008)$ & $(0.004)$ & $(0.009)$ \\
Household size & 0.871858 & 0.865992 & 0.786084 & 0.769214 & 0.744592 \\
& $(0.001)$ & $(0.001)$ & $(0.001)$ & $(0.001)$ & $(0.001)$ \\
SEDI values & 0.575669 & 0.575983 & 0.550751 & 0.546286 & 0.533856 \\
& $(0.001)$ & $(0.001)$ & $(0.001)$ & $(0.001)$ & $(0.001)$ \\
Gender Equality Index & 0.43386 & 0.434787 & 0.456966 & 0.455105 & 0.446682 \\
& $(0.001)$ & $(0.001)$ & $(0.001)$ & $(0.001)$ & $(0.001)$ \\
\hline
\end{tabular}




\section{Appendix D}

USA Cluster Map. RoOK, I INSH 1999 peem)

7 Mot Signticant: (48)

Lawlow $[15]$

$\square$ Lawhigh (3)

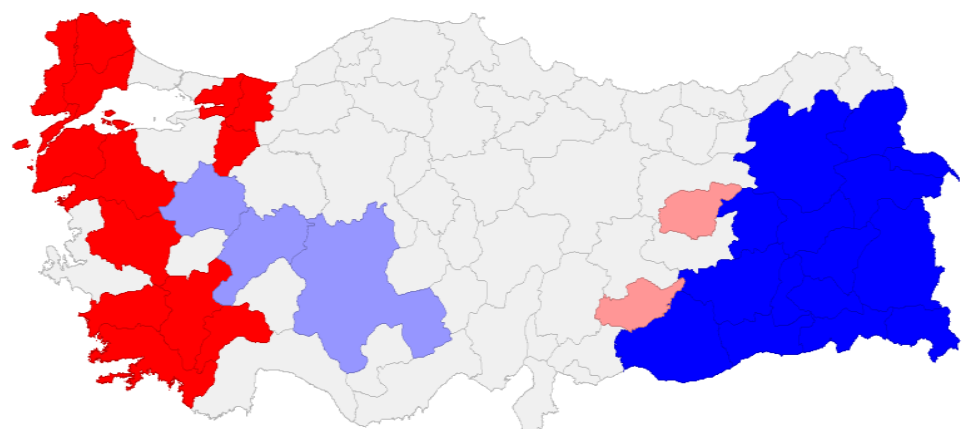

Figure D1. LISA cluster map: Women Employment's Share in total employment for all provinces in Turkey

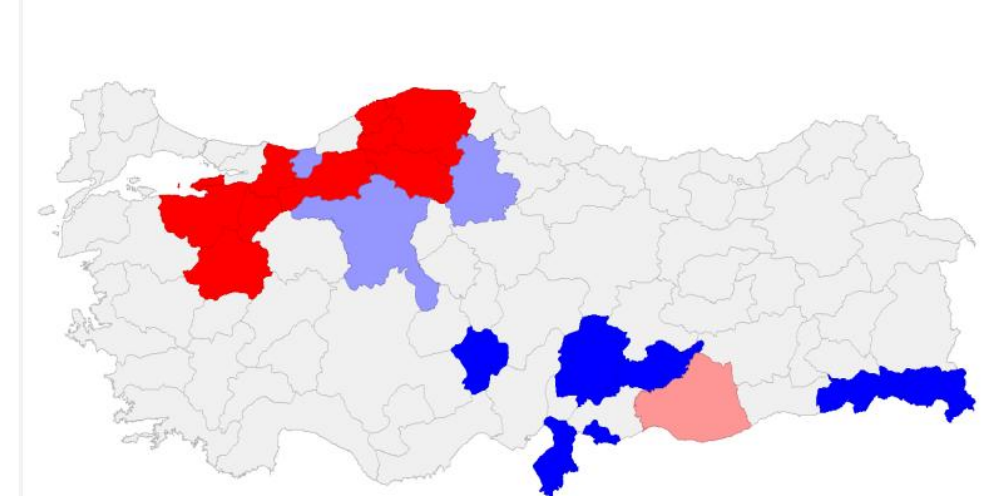

Figure D2. LISA cluster map: Wages difference for all provinces in Turkey 
Fatih CELEBIOGLU

$\square$ Not Sigificat (15)

Lowlow (20)

$\square$ Highlow (0)

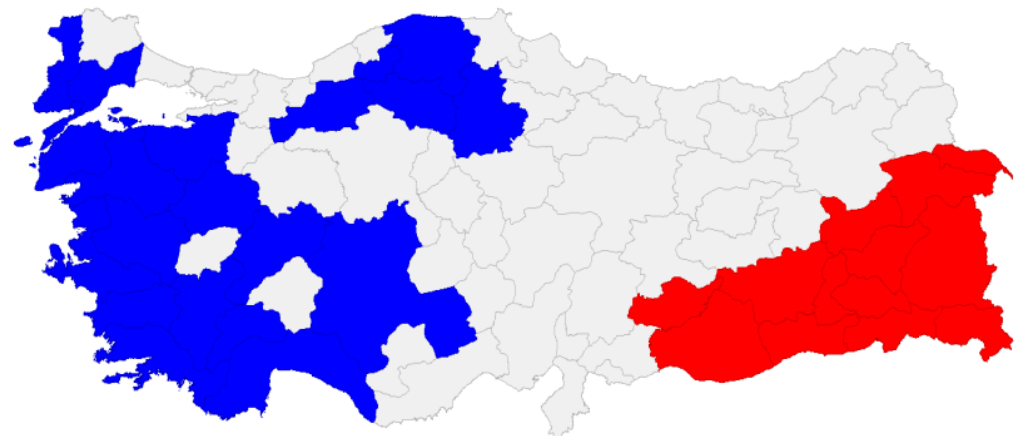

Figure D3. LISA cluster map: Household size for all provinces in Turkey

USA Cister Hap, ROOK, ISEON (P99 peem

$\square$ Mod Sigñarat 36

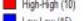

Low tithition

$\square$ Hightar if

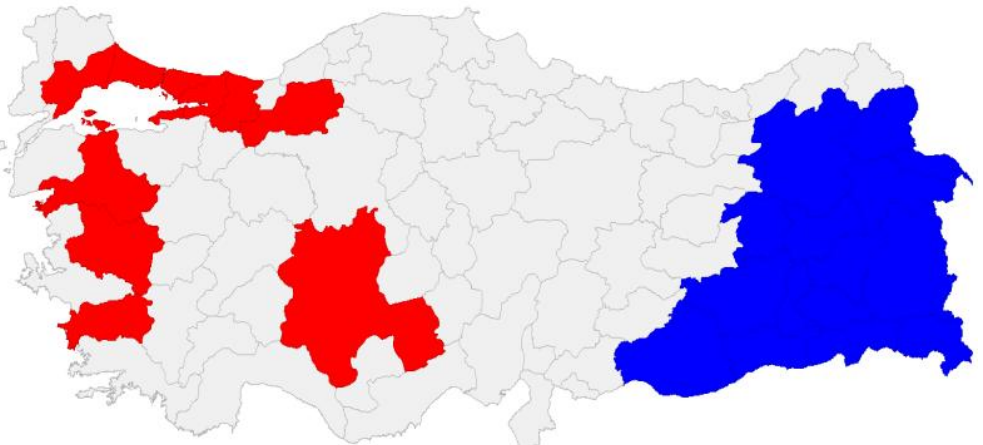

Figure D4. LISA cluster map: SEDI values for all provinces in Turkey 


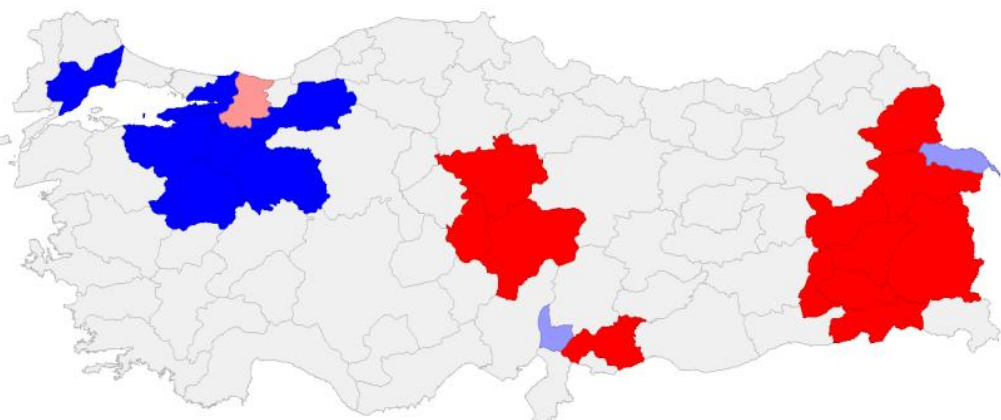

Figure D5. LISA cluster map: Gender Equality Index

\section{Appendix E}

\section{Table E1. Classic OLS regression results}

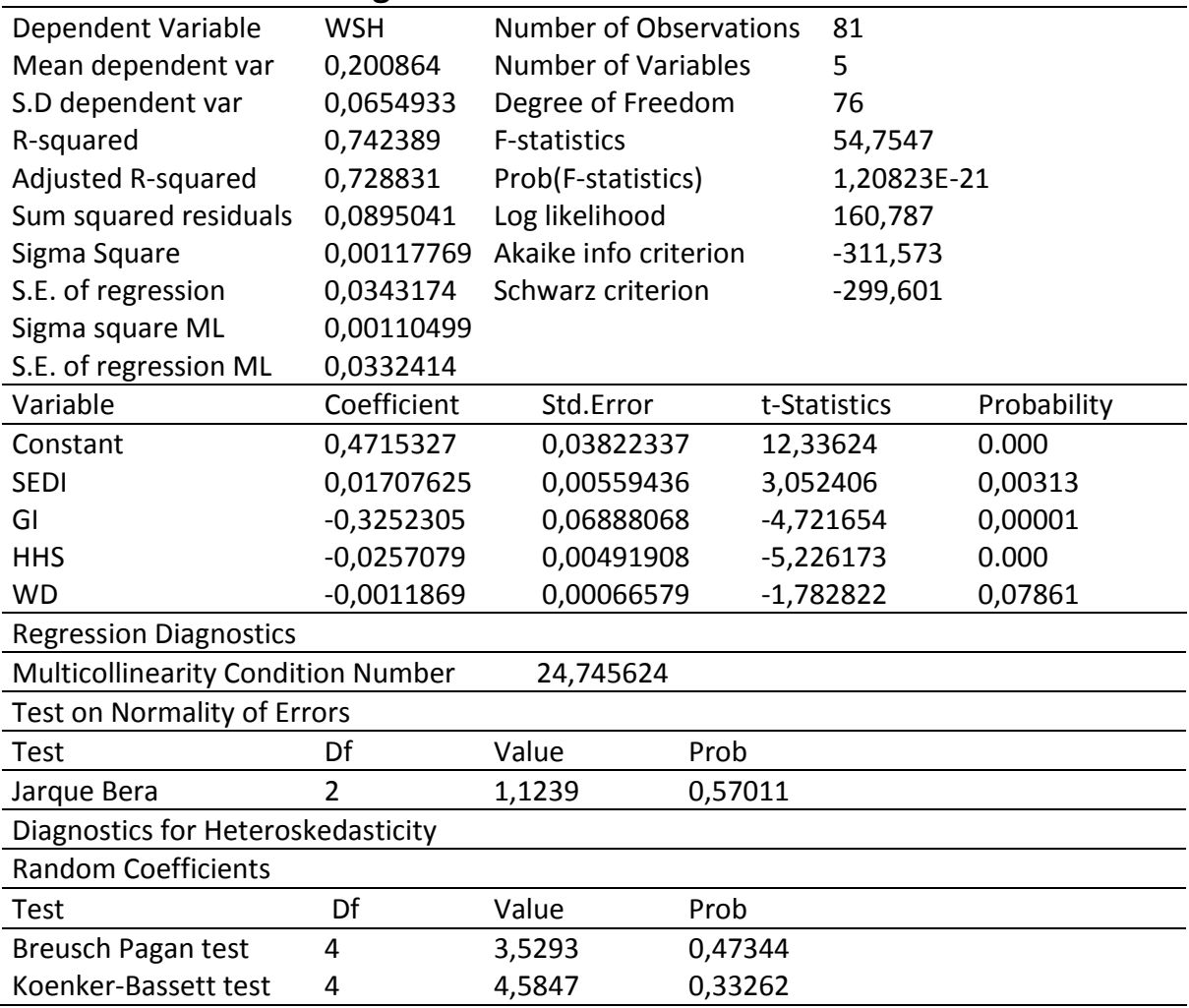


Table E2. OLS regression results with weight matrix (rook)

\begin{tabular}{|c|c|c|c|c|c|}
\hline Dependent Variable & WSH & & \multicolumn{2}{|c|}{ Number of Observations } & 81 \\
\hline Mean dependent var & & 0,200864 & \multicolumn{2}{|c|}{ Number of Variables } & 5 \\
\hline S.D dependent var & & 0,0654933 & \multicolumn{2}{|c|}{ Degree of Freedom } & 76 \\
\hline R-squared & & 0,742389 & \multicolumn{2}{|c|}{ F-statistics } & 54,7547 \\
\hline Adjusted R-squared & & 0,728831 & \multicolumn{2}{|c|}{ Prob (F-statistics) } & $1,20823 E-21$ \\
\hline Sum squared residuals & & 0,0895041 & \multicolumn{2}{|l|}{ Log likelihood } & 160,787 \\
\hline Sigma Square & & 00117769 & \multicolumn{2}{|c|}{ Akaike info criterion } & $-311,573$ \\
\hline S.E. of regression & & 0,0343174 & \multicolumn{2}{|c|}{ Schwarz criterion } & $-299,601$ \\
\hline Sigma square ML & \multicolumn{2}{|c|}{0,00110499} & & & \\
\hline S.E. of regression ML & \multicolumn{2}{|c|}{0,0332414} & & & \\
\hline Variable & \multicolumn{2}{|c|}{ Coefficient } & Std.Error & t-Statistics & Probability \\
\hline Constant & \multicolumn{2}{|c|}{0,4715327} & 0,03822337 & 12,33624 & 0.000 \\
\hline SEDI & \multicolumn{2}{|c|}{0,01707625} & 0,005594358 & 3,052406 & 0,00313 \\
\hline GI & \multicolumn{2}{|c|}{$-0,3252305$} & 0,06888068 & $-4,721654$ & 0,00001 \\
\hline HHS & \multicolumn{2}{|c|}{$-0,02570797$} & 0,004919081 & $-5,226173$ & 0.000 \\
\hline WD & \multicolumn{2}{|c|}{$-0,0011869$} & 0,000665791 & $-1,782822$ & 0,07861 \\
\hline \multicolumn{6}{|l|}{ Regression Diagnostics } \\
\hline \multicolumn{3}{|c|}{ Multicollinearity Condition Number } & \multicolumn{2}{|c|}{24,745624} & \\
\hline \multicolumn{6}{|c|}{ Test On Normality Of Errors } \\
\hline Test & \multicolumn{2}{|c|}{ Df } & Value & & Prob \\
\hline Jarque Bera & 2 & & 1,1239 & & 0,57011 \\
\hline Diagnostics Fot Heteros & kedas & sticity & & & \\
\hline Random Coefficients & & & & & \\
\hline Test & $f$ & & Value & & Prob \\
\hline Breusch Pagan test & + & & 3,5293 & & 0,47344 \\
\hline Koenker-Bassett test & & & 4,5847 & & 0,33262 \\
\hline Diagnostics for Spatial D & epen & idence & & & \\
\hline $\begin{array}{l}\text { For Weight Matrix } \\
\text { (row-standardized weig }\end{array}$ & $\begin{array}{r}\text { ROC } \\
\text { hts) }\end{array}$ & OK.gal & & & \\
\hline Test & & Mi/Df & Value & & Prob \\
\hline Moran's I (error) & & 0,3282 & 5,1972 & & 0.000 \\
\hline Lagrange Multiplier (lag & & 1 & 19,3346 & & 0,00001 \\
\hline Robust LM (lag) & & 1 & 2,6186 & & 0,10561 \\
\hline Lagrange Multiplier (err & or) & 1 & 19,3719 & & 0,00001 \\
\hline Robust LM (error) & & 1 & 2,6559 & & 0,10316 \\
\hline Lagrange Multiplier (SA) & RMA) & 2 & 21,9905 & & 0,00002 \\
\hline
\end{tabular}


Table E3. Spatial Lag Model results with weight matrix (rook)

\begin{tabular}{|c|c|c|c|c|c|c|}
\hline \multirow{4}{*}{\multicolumn{2}{|c|}{$\begin{array}{l}\text { Dependent variable } \\
\text { Mean dependent var } \\
\text { S.D. dependent variable } \\
\text { Lag coef. (Rho) }\end{array}$}} & \multirow{2}{*}{\multicolumn{2}{|c|}{$\begin{array}{l}\text { WSH } \\
0,200864\end{array}$}} & \multicolumn{2}{|c|}{ Number of observations } & 81 \\
\hline & & & & Numbe & & 6 \\
\hline & & \multicolumn{2}{|c|}{0,0654933} & \multicolumn{2}{|c|}{ Degree of Freedom } & \multirow[t]{2}{*}{75} \\
\hline & & \multicolumn{2}{|c|}{0,416905} & & & \\
\hline \multirow{2}{*}{\multicolumn{2}{|c|}{$\begin{array}{l}\text { R-squared } \\
\text { Sq. correlation }\end{array}$}} & \multicolumn{2}{|c|}{0,797873} & \multicolumn{2}{|c|}{ Log likelihood } & 168,933 \\
\hline & & & & \multicolumn{2}{|c|}{ Akaike info criterion } & $-325,867$ \\
\hline \multirow{2}{*}{\multicolumn{2}{|c|}{$\begin{array}{l}\text { Sigma Square } \\
\text { S.E. of regression }\end{array}$}} & \multicolumn{2}{|c|}{$-0,000866998$} & \multirow{2}{*}{\multicolumn{2}{|c|}{ Schwarz criterion }} & \multirow[t]{2}{*}{$-311,5$} \\
\hline & & 0,02944 & & & & \\
\hline Variable & \multicolumn{2}{|c|}{ Coefficient } & \multicolumn{2}{|c|}{ Std.Error } & $z$-value & Probability \\
\hline W_WSH & \multicolumn{2}{|c|}{0,4169052} & \multicolumn{2}{|c|}{0,09923926} & 4,20101 & 0.000 \\
\hline Constant & \multicolumn{2}{|c|}{0,3460392} & \multicolumn{2}{|c|}{0,04661679} & 7,42306 & 0.000 \\
\hline SEDI & \multicolumn{2}{|c|}{0,009082} & \multicolumn{2}{|c|}{0,005090734} & 1,784115 & 0,0744 \\
\hline GI & \multicolumn{2}{|c|}{$-0,3139434$} & \multicolumn{2}{|c|}{0,05961477} & $-5,266202$ & 0.000 \\
\hline HHS & \multicolumn{2}{|c|}{$-0,01508867$} & \multicolumn{2}{|c|}{0,004944035} & $-3,051894$ & 0,00227 \\
\hline WD & \multicolumn{2}{|c|}{$-0,001544331$} & \multicolumn{2}{|c|}{0,000574869} & $-2,686406$ & 0,00722 \\
\hline \multicolumn{7}{|c|}{ Regression Diagnostics } \\
\hline \multicolumn{7}{|c|}{ Diagnostics for heteroskedasticity } \\
\hline \multicolumn{7}{|c|}{ Random Coefficients } \\
\hline Test & & \multicolumn{2}{|c|}{ Df } & Val & & Prob \\
\hline Breuch-Pagan test & & 4 & & 1,9 & & 0,74355 \\
\hline Diagnostics for Spa & atial D & ependence & & & & \\
\hline Spatial Lag Depend & dence & for weight & atrix & & & \\
\hline Test & & Df & & Val & & Prob \\
\hline Likelihood Ratio Te & est & 1 & & 16 , & & 0,00005 \\
\hline
\end{tabular}


Fatih CELEBIOGLU

Table E4. Spatial Error Model results with weight matrix (rook)

\begin{tabular}{|c|c|c|c|c|c|c|}
\hline \multirow{4}{*}{\multicolumn{2}{|c|}{$\begin{array}{l}\text { Dependent variable } \\
\text { Mean dependent var } \\
\text { S.D. dependent variable } \\
\text { Lag coeff.(Lambda) }\end{array}$}} & \multirow{2}{*}{\multicolumn{2}{|c|}{$\begin{array}{l}\text { WSH } \\
0,200864\end{array}$}} & \multicolumn{2}{|c|}{ Number of observations } & 81 \\
\hline & & & & \multicolumn{2}{|c|}{ Number of variables } & 5 \\
\hline & & \multicolumn{2}{|c|}{0,065493} & \multicolumn{2}{|c|}{ Degree of Freedom } & \multirow[t]{2}{*}{76} \\
\hline & & \multicolumn{4}{|c|}{0,622655} & \\
\hline \multicolumn{2}{|l|}{ R-squared } & \multicolumn{2}{|c|}{0,818059} & \multicolumn{3}{|c|}{ R-squared (BUSE) } \\
\hline \multicolumn{2}{|l|}{ Sq. Correlation } & \multirow{2}{*}{\multicolumn{2}{|c|}{0,000780415}} & \multicolumn{2}{|c|}{ Log likelihood } & 170,67556 \\
\hline \multirow{2}{*}{\multicolumn{2}{|c|}{$\begin{array}{l}\text { Sigma Square } \\
\text { S.E. of regression }\end{array}$}} & & & \multirow{2}{*}{\multicolumn{2}{|c|}{$\begin{array}{l}\text { Akaike info criterion } \\
\text { Schwarz criterion }\end{array}$}} & $-331,351$ \\
\hline & & \multicolumn{2}{|c|}{0,0279359} & & & $-319,379$ \\
\hline Variable & \multicolumn{2}{|c|}{ Coefficient } & \multicolumn{2}{|c|}{ Std.Error } & z-value & Probability \\
\hline Constant & \multicolumn{2}{|c|}{0,4785233} & \multicolumn{2}{|c|}{0,03513756} & 13,61857 & 0.000 \\
\hline SEDI & \multicolumn{2}{|c|}{0,01248722} & \multicolumn{2}{|c|}{0,004974922} & 2,510033 & 0,01207 \\
\hline GI & \multicolumn{2}{|c|}{$-0,3637998$} & \multicolumn{2}{|c|}{0,06340813} & $-5,737432$ & 0.000 \\
\hline HHS & \multicolumn{2}{|c|}{$-0,02230517$} & \multicolumn{2}{|c|}{0,006664252} & $-3,346987$ & 0,00082 \\
\hline WD & \multicolumn{2}{|c|}{$-0,00106833$} & \multicolumn{2}{|c|}{0,000556424} & $-1,919992$ & 0,05486 \\
\hline Lambda & \multicolumn{2}{|c|}{0,6226552} & \multicolumn{2}{|c|}{0,1012188} & 6,151579 & 0,000 \\
\hline $\begin{array}{l}\text { Regression Diagno } \\
\text { Diagnostics for het }\end{array}$ & $\begin{array}{l}\text { stics } \\
\text { erosk }\end{array}$ & dasticit & & & & \\
\hline Random Coefficier & & & & & & \\
\hline Test & & $f$ & & Valu & & Prob \\
\hline Breuch-Pagan test & & + & & 1,74 & & 0,78223 \\
\hline Diagnostics for $\mathrm{Spa}$ & tial D & pender & & & & \\
\hline Spatial Error Depe & ndenc & for we & 1 & & & \\
\hline Test & & $f$ & & Valu & & Prob \\
\hline Likelihood Ratio T€ & st & 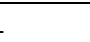 & & 19,7 & & 0,00001 \\
\hline
\end{tabular}

\section{Appendix F}

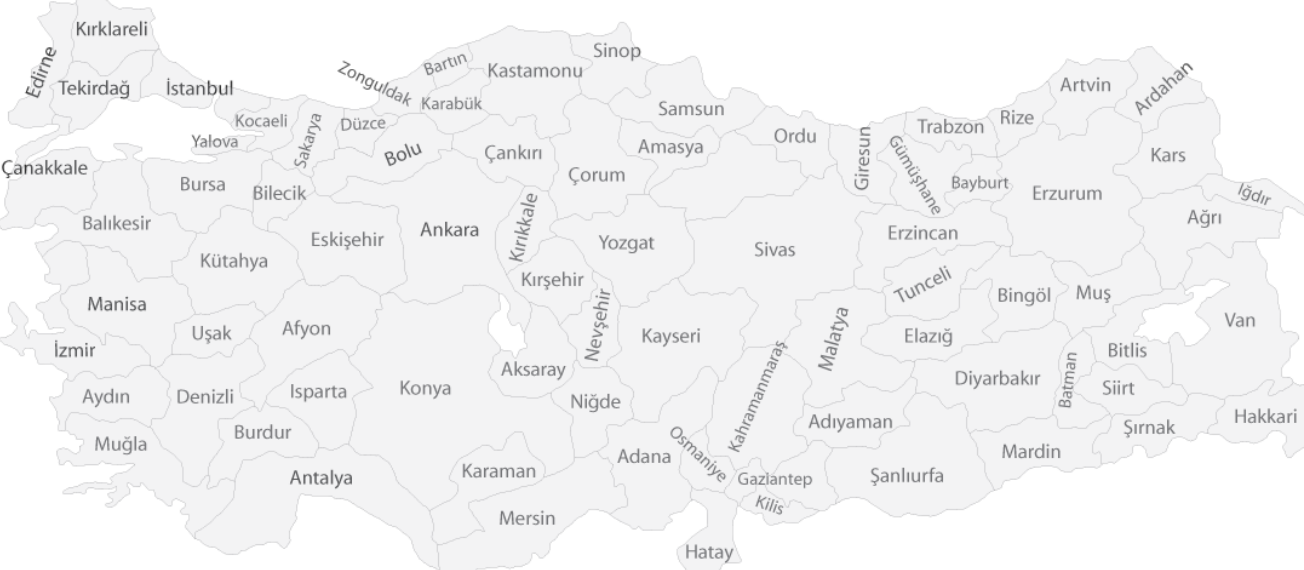

Figure F1. Location and Names of Provinces in Turkey 